\title{
Keeping It Simple: Comparative Analysis of TFP across Manufacturing Industries and Major States of India
}

\author{
Awadhesh Pratap Singh \\ Indian Institute of Management Lucknow, Lucknow, India \\ Email: awadheshp2000@gmail.com
}

How to cite this paper: Singh, A.P. (2017) Keeping It Simple: Comparative Analysis of TFP across Manufacturing Industries and Major States of India. Theoretical Economics Letters, 7, 1821-1833. https://doi.org/10.4236/tel.2017.76124

Received: September 15, 2017

Accepted: October 27, 2017

Published: October 30, 2017

Copyright $\odot 2017$ by author and Scientific Research Publishing Inc. This work is licensed under the Creative Commons Attribution International License (CC BY 4.0).

http://creativecommons.org/licenses/by/4.0/

Open Access

\begin{abstract}
The measurement of total factor productivity in Indian economic development has been greatly debated especially after economic reforms set in. While a fair amount of research is done on this subject, however the findings were lost in the shadow of complex econometric techniques. This paper is an honest attempt to simplify the complex area of productivity for a geographically multifaceted country-India. The paper carries out a comprehensive and comparative TFP (total factor productivity) analysis across 19 major India states and their 15 Indian manufacturing industries. The intent of this paper is fourfold. First, it estimates TFP using a simple technique (growth accounting). Second, it performs the state and the industry level comparative TFP analysis. Third, it discusses the outliers and justifies their outcomes and fourth provides recommendations for policy making and states the implications.
\end{abstract}

\section{Keywords}

Total Factor Productivity, Growth Accounting, Labor Productivity, India

\section{Introduction}

It is rightly said by someone "Simplicity is a virtue for comparisons". In today's world where it is important to utilize new techniques to carry out research, it is also equally important to simplify the methodologies and their results. One of the best examples that fit in here is comparative productivity analysis in the context of India. While a fair amount of research is done on this subject, however the findings were looked to be lost while translating the outcome from complex methodologies. Most of the studies written on this subject were either focused on industry level or state level, however a holistic canvas that could carry 
both together (states and industries) and portray its findings in a simplified manner was largely ignored. This paper is an honest attempt to simplify the complex area of comparative productivity analysis for a geographically multifaceted country-India. The intent of this paper is multifold: first: it uses a simple technique growth accounting (Solow Residual) to estimate productivity and simplify its findings. Second: it takes 19 major Indian states and their 15 manufacturing industries into account; this therefore, performs a comparative analysis of TFP (total factor productivity) at good disaggregated level. Third: it takes good care of data, measurement and variable issues which have generated good amount of debate in the past two decades and showed by Kathuria et al. [1]. Fourth, it makes policy recommendations and contributes towards productivity literature in the context of India.

The paper has been divided into 4 sections: In first section, the paper defines growth accounting and carries out productivity literature review in the context of India. The second section explains data, variables and their preparation. The third section carries out the TFP estimation and analyses the results. Finally, the fourth section concludes findings with policy recommendations.

\section{Growth Accounting and Key Research in Productivity in India}

In Economics literature, productivity is measured by production function and is commonly referred as TFP. With capital and labor, the production function in Cobb-Douglas form is formulated as below:

$$
Y=A+K^{\alpha}+L^{\beta}
$$

The above equation represents total output $(Y)$ as a function of total-factor productivity $(A)$, capital input $(K)$, labor input $(L)$, and the two inputs' respective shares of output ( $\alpha$ and $\beta$ are the share of contribution for K and $\mathrm{L}$ respectively).

Singh [2] proposed that the simplest technique to calculate TFP is to use of growth accounting method. As the name suggests, growth accounting refers to growth in total factor productivity over time and the equation is given below:

$$
\% \Delta Y=\% \Delta A+a_{K} \cdot \% \Delta K+a_{N} \cdot \% \Delta N
$$

In the above equation\% $\Delta Y$ represents growth in potential output/year, $\% \Delta K$ is the growth in the capital stock/year, $\% \Delta N$ is termed as growth in the labor supply/year, $\% \Delta A$ is termed as growth in total factor productivity/year, $a_{K}$ is represented as $\% \Delta Y / \% \Delta \mathrm{K}$ or elasticity of output with respect to capital (holding $A$ and $N$ fixed) and $a_{N}$ is termed as $\% \Delta Y / \% \Delta \mathrm{N}$ or elasticity of output with respect to labor (holding $A$ and $K$ fixed).

\section{Productivity: Research in India}

Kathuria et al. [1] concluded thatin the context of India, studies on productivity can be broadly divided into 2 generations: traditional and advanced. Traditional 
studies are focused majorly on 3 techniques, namely: Growth Accounting, Data Envelop Analysis (DEA in short) and Stochastic Frontier Analysis (SFA in short). Singh [2] explained that advanced techniques are majorly focused on unit (firm) level data. Olley and Pakes (OP in short [3]), Levinsohn and Petrin (LP in short [4]), Ackerberg, Caves and Frazer (ACF in short [5]), Wooldridge [6] are few of the popular techniques from the advanced generations.

Goldar [7] and Goldar [8] and Goldar and Kumari [9] were the first few researchers who used growth accounting techniques by employing industry data. Kulshreshtha and Parikh [10] and Deshpande and Weisskopf [11] used DEA and Kathuria et al. [1] used SFA. Using firm level data, LP [4] was used widely by Mitra et al. [12], Sharma and Mishra [13], Singh [2].

Table 1 exhibits some of the important productivity studies in the context of India after 1980. Few conclusions can be drawn from Table 2. First, while fair amount of work is done using industry and unit level of datasets, the twopronged comparative analysis approach that comprises state and industry together was largely ignored. Second, baring few occasions (Goldar and Kumari [9]; Kathuria et al. [1] and Kathuria et al. [14]), the scale of which data was taken is relatively smaller. Third, only few authors (Mitra et al. [15]; Singh [2]) worked on the recent datasets; and fourth, simplifying the findings was somewhat lost in shadow of complex econometric techniques and that is the basic premise of this paper.

In the light of the above findings, the intent of this productivity analysis is fourfold. First, estimate TFP using a simple technique (growth accounting). Second, perform the state and the industry level comparative TFP analysis. Third, discuss the outliers (state and industry levels) and justify their outcomes and fourth provide recommendations for policy making, implications of the outcomes and scope for further research.

By looking at the intents of this paper and comparing it with the literature presented in Table 1, the most important aspect of this paper is to carry out comparative analysis across 19 major Indian states and their 15 manufacturing industries against TFP growth through a simplistic measure: growth accounting.

\section{Data, Variables and TFP Growth}

ASI database (Annual Survey of Industries) is employed to collect the information of Indian manufacturing firms from 1998 to 2011. The sample covers 15 industries: Tobacco (16), Textiles (17), Apparel (18), Leather (19), Wood and Products of Wood (20), Paper and Paper Products (21), Manufacture of Coke (23), Refined Petroleum Products and Nuclear Fuel (24), Rubber and Plastic Products (25), Other Non-Metallic Mineral Products (26), Basic Metals (27), Machinery and Equipment's N.E.C, Motor Vehicles (29), Trailers and SemiTrailers (34) and Other Transport Equipment (35) and 19 Major Indian States: Andhra Pradesh, Uttar Pradesh, Gujrat, Madhya Pradesh, Tamil Nadu, West Bengal, Uttarakhand, Jharkhand, Chhattisgarh, Jammu and Kashmir, Haryana, 
Table 1. Productivity Studies for India after 1980.

\begin{tabular}{|c|c|c|c|c|}
\hline Research (year) & Period & Primary Data Source)/Scale & Objectives & Major Findings \\
\hline Goldar [7] & $1951-1979$ & $\begin{array}{l}\text { Industry level Data (ASI)/ } \\
8 \text { manufacturing industries }\end{array}$ & $\begin{array}{l}\text { Determine productivity } \\
\text { growth for manufacturing } \\
\text { industry }\end{array}$ & $\begin{array}{l}\text { Results indicate that productivity fluctuates } \\
\text { across industries }\end{array}$ \\
\hline $\begin{array}{ll}\text { Krishna } & \text { and } \\
\text { Mitra [16] } & \end{array}$ & 1986-1993 & $\begin{array}{l}\text { Firm level panel data (CMIE)/ } \\
4 \text { manufacturing industries }\end{array}$ & $\begin{array}{l}\text { Investigates the effects on } \\
\text { competition and } \\
\text { productivity }\end{array}$ & $\begin{array}{l}\text { Found strong evidence of an increase in } \\
\text { competition and some evidence of an } \\
\text { increase in productivity growth }\end{array}$ \\
\hline $\begin{array}{l}\text { Kulshreshtha } \\
\text { and Parikh [10] }\end{array}$ & $1985-1997$ & $\begin{array}{l}\text { Industry level Data (ASI)/ } \\
\text { Coal Industry }\end{array}$ & $\begin{array}{l}\text { Study efficiency and } \\
\text { productivity of coal sector }\end{array}$ & $\begin{array}{l}\text { Declining of productivity has been reported } \\
\text { in most of the cases }\end{array}$ \\
\hline $\begin{array}{l}\text { Goldar and } \\
\text { Kumari [9] }\end{array}$ & 1981-1998 & $\begin{array}{l}\text { Industry level Data (ASI)/ } \\
17 \text { manufacturing industries }\end{array}$ & $\begin{array}{l}\text { Compare growth rate of } \\
\text { TFP in the } 1990 \text { s, with } \\
\text { that in the } 1980 \mathrm{~s}\end{array}$ & $\begin{array}{l}\text { Estimated productivity growth in the } 1990 \text { s } \\
\text { is found to be about the same as in the } \\
1980 \text { s. }\end{array}$ \\
\hline Unel [17] & $1979-1988$ & $\begin{array}{l}\text { Industry level Data (ASI)/ } \\
13 \text { manufacturing industries }\end{array}$ & $\begin{array}{l}\text { Investigates productivity } \\
\text { trends during 1980s and } \\
1990 \text { s }\end{array}$ & $\begin{array}{l}\text { Labor and TFP growth since } 1980 \text { s were } \\
\text { markedly higher than those of preceding } \\
\text { two decades }\end{array}$ \\
\hline Goldar [8] & $1981-1998$ & $\begin{array}{l}\text { Industry level Data (ASI)/ } \\
8 \text { manufacturing industries }\end{array}$ & $\begin{array}{l}\text { Compare pre-reforms } \\
\text { period (before 1992) with } \\
\text { post reforms }\end{array}$ & $\begin{array}{l}\text { No difference in productivity growth } \\
\text { between pre-reform and post reform } \\
\text { periods }\end{array}$ \\
\hline $\begin{array}{l}\text { Kathuria et al. } \\
\text { [14] }\end{array}$ & 1994-2006 & $\begin{array}{l}\text { Firm level data (NSSO and ASI)/ } \\
\text { for } 15 \text { industries }\end{array}$ & $\begin{array}{l}\text { Analyzed productivity } \\
\text { performance of formal } \\
\text { and informal sectors }\end{array}$ & $\begin{array}{l}\text { Labor productivity increased in organized } \\
\text { sector over time. Labor productivity and } \\
\text { capital intensity growth slowed down for } \\
\text { unorganized sector }\end{array}$ \\
\hline $\begin{array}{l}\text { Kathuria et al. } \\
\text { [1] }\end{array}$ & $\begin{array}{l}1994-95 \\
2000-01 \\
\text { and } \\
2005-06\end{array}$ & $\begin{array}{l}\text { Firm level Data (ASI)/Formal } \\
\text { and informal sectors across } 15 \\
\text { major states }\end{array}$ & $\begin{array}{l}\text { Paper computes TFP } \\
\text { using SPF, production } \\
\text { function and growth } \\
\text { accounting }\end{array}$ & $\begin{array}{l}\text { TFP growth of formal and informal sector } \\
\text { differed greatly during this period and that } \\
\text { the estimates are sensitive to the technique } \\
\text { used }\end{array}$ \\
\hline Mitra et al. [12] & 1994-2008 & $\begin{array}{l}\text { Firm level Data (CMIE)/ } \\
8 \text { manufacturing industries }\end{array}$ & $\begin{array}{l}\text { Assess, the role of export } \\
\text { and import, R\&D, } \\
\text { technology transfer, and } \\
\text { infrastructure }\end{array}$ & $\begin{array}{l}\text { Results suggest that infrastructure is a } \\
\text { crucial determinant of manufacturing } \\
\text { performance in India }\end{array}$ \\
\hline $\begin{array}{l}\text { Deshpande and } \\
\text { Weisskopf [11] }\end{array}$ & $1980-2002$ & $\begin{array}{l}\text { Sector level data (Indian } \\
\text { Railway)/ Indian railways }\end{array}$ & $\begin{array}{l}\text { Asses relation between } \\
\text { members of marginalized } \\
\text { communities and TFP }\end{array}$ & $\begin{array}{l}\text { No evidence for such an effect is found that } \\
\text { reservation to marginalized community } \\
\text { impacts productivity in fact the opposite is } \\
\text { true. }\end{array}$ \\
\hline $\begin{array}{l}\text { Sharma and } \\
\text { Mishra [13] }\end{array}$ & 1994-2006 & $\begin{array}{l}\text { Firm level panel data (Prowess)/ } \\
4 \text { manufacturing industries }\end{array}$ & $\begin{array}{l}\text { Explores linkages between } \\
\text { trade and productivity } \\
\text { performance }\end{array}$ & $\begin{array}{l}\text { Exporters, importers are more productive. } \\
\text { Reported positive effect of R\&D on labor } \\
\text { productivity }\end{array}$ \\
\hline Mitra et al. [15] & $1994-2010$ & $\begin{array}{l}\text { Firm level panel data (Prowess)/ } \\
8 \text { manufacturing industries }\end{array}$ & $\begin{array}{l}\text { Find Links among TFP, } \\
\text { ICT and infrastructure }\end{array}$ & $\begin{array}{l}\text { The impact of infrastructure and ICT } \\
\text { (information and communication } \\
\text { technology) is strong on TFP }\end{array}$ \\
\hline $\begin{array}{l}\text { Singh [2] and } \\
\text { Singh [18] }\end{array}$ & 2001-2012 & $\begin{array}{l}\text { Firm level panel data (Prowess)/ } \\
3 \text { manufacturing industries }\end{array}$ & $\begin{array}{l}\text { Find the relationship } \\
\text { between TFP and } \\
\text { technology spillovers }\end{array}$ & $\begin{array}{l}\text { Technology spillovers, productivity gain } \\
\text { and internationalization of firms are closely } \\
\text { linked }\end{array}$ \\
\hline
\end{tabular}

Source: the table has been created by author. The contents (primary data sources, objectives and major findings) were accessed by the respective papers mentioned in the table below as well in References section 
Himachal Pradesh, Kerala, Karnataka, Orissa, Punjab, Bihar, Rajasthan and Maharashtra.

The industries and states are picked up based on availability of data from the ASI database and their relevance to this paper. Indian has 29 states, however this paper only took 19 . The reason to omit the other 10 states is due to two reasons: first, these states are very small and hardly impact the results. Second, the data was not available in many cases for all the years.

The rationale for picking up the 15 industries is twofold: first, they are the major industries in the states chosen and covers the wide population. Second, several states carried our wide variety of reforms across these industries and our intent is to capture the impact.

While our assumption is to reflect the TFP trends of major states and their major industries, two disadvantages could be associated with this approach: first, omitted small states could unearthed interesting findings. Second, emerging industries that have been omitted in our sample, could lead to exciting observations.

The data series retrieved to carry out the analysis for this paper are: total persons engaged, fuel consumed, depreciation, gross value added, materials consumed and net fixed capital stock. An important fact to note here is ASI changed its industry classification two times during the period considered for this paper: firstly in 2003-04 and then subsequently in 2007-08. Therefore, to ensure the data sanctity and consistency, the 2 digits industries taken for this paper, have been compared, reclassified and rearranged appropriately. During this process, the industries that author could not compare and classify, have been taken out.

Real gross value series has been constructed by deflating the nominal data series by the wholesale price index for the manufacturing industries taken. 1998 has been taken as the base year. total number of persons engaged has been taken as the measure of labor input. To build capital series, the author employed the method suggested by Krishna, Kapila [19]. The method employs net fixed capital stock at constant prices as the measure of capital inputs. To obtain material inputs at constant prices, the series on material has been deflated. The deflator is formed as a weighted average of price indices for various input-output sectors. For each sector, wholesale price indices have been employed. The input output table for 1993-94 published by CSO (Central Statistical Organization) has been used for this purpose. Energy inputs at constant prices have been obtained in the same manner as it was done for materials.

Variables used in this paper, their definition, deflators (as applicable) and sources are given in Table 2.

\section{Total Factor Productivity: Comparative Analysis}

The paper uses 3 different variables to compute TFP-first, labor (L) which indicates workers engaged. Second, capital (K) that shows capital involved. Third, output that shows the gross value added by the firms. The study carries out the 
Table 2. Variables used in this study, deflators user and their database source.

\begin{tabular}{|c|c|c|c|}
\hline Variable & Definition & Deflator & Data Source \\
\hline Output (Q) & $\begin{array}{l}\text { Gross value added } \\
\text { (GVA) to the firm }\end{array}$ & $\begin{array}{c}\text { Deflated by industry specific Wholesale } \\
\text { Price indices (WPI) }\end{array}$ & $\begin{array}{l}\text { - GVA obtained Annual Survey of Industries } \\
\text { (EPW) } \\
\text { - WPI obtained from the Ministry of Commerce } \\
\text { \& Industry of India ( } \underline{\text { http://eaindustry.nic.in) }}\end{array}$ \\
\hline Labor $(\mathrm{N})$ & Total persons engaged & - & $\begin{array}{l}\text { - Total persons engaged obtained from Annual } \\
\text { Survey of Industries (EPW) }\end{array}$ \\
\hline Capital (K) & $\begin{array}{l}\text { Fixed capital stock series } \\
\text { constructed by perpetual } \\
\text { inventory method }\end{array}$ & $\begin{array}{l}\text { Deflator is derived from the data on gross } \\
\text { fixed capital formation in registered manu- } \\
\text { facturing at current and constants prices } \\
\text { given in NAS }\end{array}$ & $\begin{array}{l}\text { - Net fixed capital formation obtained from } \\
\text { Annual Survey of Industries (EPW) } \\
\text { - Deflator obtained from Macroeconomic } \\
\text { Aggregates (https://data.gov.in) }\end{array}$ \\
\hline
\end{tabular}

Source: the table has been created by author. It is to define the variables (data) used and how the data is prepared.

analysis in two periods-first between 1999-2004 and the second between 20052011. The reason for choosing these two periods is due to change in regime. In the first half (1999-2004), United Progressive Alliance was ruling the country, whereas in the second half (2005-2011), it was National Democratic Alliance that ruled the state.

The paper uses growth accounting technique due to four reasons. First, the primary goal of this study is to estimate how much output, on average, has been acquired from a set of inputs, hence growth accounting approach is a better choice. Second, the intent of this paper is to simplify the findings and draw trends and patterns. Growth accounting simply fits the bill. Third, while few other researchers used growth accounting (Goldar [7]; Goldar and Kumari [9]), the dataset employed by this paper is recent (1998-99 to 2011-12). Fourth and most importantly, the dataset used in this paper is industry focused, therefore other advanced firm level techniques such as OP, LP, ACF and Wooldridge may not be useful (Singh [18]), however in the virtue of simplicity, growth accounting scores over others. While growth accounting is suitable to simplify the findings, it does have two major constraints as well: first, it may overstate the TFP growth and second, it may have endogeneity issues if the variables are not chosen carefully.

We will carry out the analysis in 2 stages. First: TFP growth will be calculated by aggregating industries on state level (aggregated level). Second: TFP growth will then be calculated for each industry and state level (disaggregated level). The productivity estimates for the period 1998-2011 will be bifurcated into two parts-first from 1999 to 2004 and second, from 2005 to 2011. The reason to calculate TFP in these two periods is due to change in regime (United Progressive Alliance came to power in 2005).

\subsection{TFP Growth: Comparative Analysis across States by Aggregating Industries}

Table 3 shows the mean TFP growth across 19 different states of India for two periods. 
Table 3. Mean TFP growth across 19 major Indian states.

\begin{tabular}{|c|c|c|}
\hline State & First half-1999-2004 & Second half-2005-2011 \\
\hline Andhra Pradesh & $-10.49 \%$ & $-12.35 \%$ \\
\hline Gujarat & $-11.64 \%$ & $-13.15 \%$ \\
\hline Haryana & $-18.91 \%$ & $4.69 \%$ \\
\hline Karnataka & $-27.64 \%$ & $-13.10 \%$ \\
\hline Kerala & $-8.63 \%$ & $-34.33 \%$ \\
\hline Madhya Pradesh & $-6.78 \%$ & $11.03 \%$ \\
\hline Maharashtra & $-10.96 \%$ & $1.87 \%$ \\
\hline Uttar Pradesh & $-11.86 \%$ & $-13.23 \%$ \\
\hline Rajasthan & $-31.55 \%$ & $-32.74 \%$ \\
\hline West Bengal & $-8.62 \%$ & $-13.93 \%$ \\
\hline Tamil Nadu & $-12.13 \%$ & $-15.18 \%$ \\
\hline Bihar & $-57.45 \%$ & $2.85 \%$ \\
\hline Himachal Pradesh & $-4.31 \%$ & $-33.02 \%$ \\
\hline Orissa & $-11.26 \%$ & $51.97 \%$ \\
\hline Jammu and Kashmir & $-47.03 \%$ & $-0.27 \%$ \\
\hline Punjab & $-15.23 \%$ & $-41.29 \%$ \\
\hline Uttarakhand & $-66.81 \%$ & $-75.50 \%$ \\
\hline Jharkhand & $-2.40 \%$ & $-33.40 \%$ \\
\hline Chhattisgarh & $-48.08 \%$ & $-29.09 \%$ \\
\hline Mean & $-22.83 \%$ & $-20.32 \%$ \\
\hline
\end{tabular}

Notes: Estimated from the data without outliers; light shaded are the states for which there is improvement in TFPG from negative to positive.

Three important observations can be made from Table 3. First, Haryana, Madhya Pradesh, Maharashtra, Bihar and Orrisa are the 5 states where TFP growth has seen a turnaround from negative to positive direction. Incidentally, all these states are large to medium in size in terms of their area and population. Second, the biggest increment has been reported in the case of Orissa where \% change in TFP growth is about $63 \%$. Third, the biggest drop has been reported in Jharkhand with $31 \%$ fall in productivity followed by Himachal Pradesh $(28.71 \%)$ and Kerala (24.7\%).

Interestingly, three surprises have been reported as well. First, J\&K shows a turnaround from negative to moving towards positive direction. The major driver for this boost was special focus on tourism (India Ministry of Tourism [20]), sericulture and cold-water fisheries during the period of 2005-11. While the TFP growth was still not positive, however the improvement was significant. Second: Punjab being a prosperous state could not record positive productivity figures in these two periods. A major weakness had been its high fiscal deficit, which is the highest among all major states-budgeted at 3.4\% of GDP for 
2011-12. The high fiscal deficit arises mainly out of huge unwarranted subsidies, the chief culprit being free power to farmers. Interestingly, Economic Freedom Index published by Wall Street Journal, Punjab's rank has slipped badly from the $6^{\text {th }}$ position in 2005 to the $12^{\text {th }}$ position in 2011. Third: Orissa and Bihar despite of termed as slightly backward states, reported positive TFP growth. For Orissa, the primary reason is good investments in infrastructural facilities. For example: in 2004 onwards, the transportation system in Orissa, was upgraded with wellmaintained road network and international airport at Bhubaneswar (capital of Orissa), major ports and rail network connecting all major cities of the country. Besides, Steel and Power sector also led to fast paced growth of the state. In case of Bihar, since November 2005, a new government has implemented many economic and social reforms. Interestingly, in June 2009, the World Bank reported that Patna (capital of Bihar) was the second-best city in India to start a business. However, the real surprise came in January 2010 when Indian government's Central Statistics Organization (CSO) reported that in the five-year period between 2005-2006 and 2008-09, Bihar's GDP grew by $11.03 \%$, which made Bihar the second fastest growing economy in India during that 5-year period.

\subsection{TFP Growth: Comparative Analysis for States and Industry Level (Disaggregated)}

Table 4 shows the mean TFP growth across 19 major Indian states and 15 different industries for 1999-04.Six important observations can be made from Table 4. First, Rubber (24), Chemical (25) and motors vehicles (29) industries demonstrated maximum fluctuation in their TFP growth across the states. Interestingly, these industries are cyclical in nature and this is the reason attributed to the observed fluctuations. Second, Other Transport equipment industry (35) that is involved in activities such as ship building, boat manufacturing and railroad rolling stocks has seen mostly the positive TFP growth across newly formed states such as Jharkhand, Uttarakhand and Chhattisgarh. An important fact to note is, all 3 states are rich in natural resources such as metal and coal. Third, Textiles industry (17) has seen good TFP growth for the major states such as Maharashtra, Gujarat Uttar Pradesh, Rajasthan, Kerala and Karnataka. These states are also biggest cotton producers. In fact, West Bengal which is the largest jute producer experienced small TFP growth in this period. Fourth, Manufacturer of woodland product (20) realized mean negative TFP growth across all the states in this period. Two reasons that could be attributed to this are: first: it is the largest non-organized sector in India and second: Indian taste has been refined in the last few years and people are looking for more western style woodland products. Fifth, the highest positive TFP was recorded by Chhattisgarh followed by Rajasthan for Other Transport equipment industry (35). The highest negative TFP was recorded by Chhattisgarh for Leather Products (19) followed by Bihar for Woodland products (20). Sixth and finally, Tamil Nadu is the only state that recorded the negative mean TFP growth across all industries in this period. Chhattisgarh too recorded negative mean TFP growth across all industry 
Table 4. Mean TFP Growth across 19 Different States of India for 15 Different Industries for 1999-04.

\begin{tabular}{|c|c|c|c|c|c|c|c|c|c|c|c|c|c|c|c|}
\hline \multicolumn{16}{|c|}{ First half-1999-2004 } \\
\hline $\begin{array}{c}\text { Industry Code/ } \\
\text { States }\end{array}$ & 16 & 17 & 18 & 19 & 20 & 21 & 23 & 24 & 25 & 26 & 27 & 28 & 29 & 34 & 35 \\
\hline Andhra Pradesh & -1.3 & -4.3 & 18.6 & 9.4 & -35.2 & -6.3 & -46.6 & -1.8 & -15.0 & -2.1 & -25.5 & -23.5 & -5.0 & -4.8 & -14.1 \\
\hline Gujarat & -16.6 & 3.4 & -0.5 & 21.3 & -21.5 & -9.8 & -51.3 & 3.8 & 4.2 & -10.5 & -17.6 & -18.5 & -5.5 & -30.0 & -25.7 \\
\hline Haryana & -15.0 & -16.2 & -41.9 & -5.8 & -26.1 & -13.1 & -73.8 & -10.6 & -16.3 & -1.2 & -13.6 & -7.9 & 5.1 & -18.9 & -28.5 \\
\hline Karnataka & -8.9 & 0.5 & -11.7 & -189.1 & -30.6 & -5.9 & -55.7 & -29.6 & -3.6 & -15.0 & -22.4 & 7.0 & -8.7 & -20.2 & -20.9 \\
\hline Kerala & -54.0 & 2.2 & -22.5 & -38.0 & -0.3 & 7.2 & -10.0 & 7.6 & -3.9 & -2.7 & 15.3 & 2.1 & 2.9 & -41.0 & 5.6 \\
\hline Madhya Pradesh & -23.7 & -4.0 & -65.6 & 0.1 & -11.4 & -6.3 & -45.2 & -4.9 & -11.8 & -2.1 & -24.3 & 3.9 & -30.2 & -21.4 & -5.0 \\
\hline Maharashtra & -2.6 & 3.4 & -5.3 & -8.6 & -18.2 & -1.7 & -28.9 & 5.8 & -16.0 & -10.8 & -21.5 & -2.7 & -3.0 & -14.8 & -39.6 \\
\hline Uttar Pradesh & -11.7 & 4.0 & -12.4 & -18.9 & -54.7 & -1.1 & -4.5 & 5.0 & 3.3 & -58.9 & 0.2 & -18.3 & 5.0 & -15.7 & 0.6 \\
\hline Rajasthan & -27.0 & 3.6 & -16.4 & -19.3 & -101.7 & -36.0 & -174 & -7.8 & -10.9 & -65.6 & -10.9 & -13.7 & -7.8 & -102.9 & 124.8 \\
\hline West Bengal & -7.1 & 0.5 & -7.3 & 3.2 & -18.3 & -10.7 & -37.0 & -21.6 & -11.8 & -21.6 & -18.2 & 0.7 & 4.3 & 21.0 & -5.7 \\
\hline Tamil Nadu & -14.4 & -6.3 & -11.3 & -7.7 & -44.4 & -18.1 & -8.9 & -1.6 & -4.8 & -7.8 & -1.1 & -5.3 & -9.1 & -19.5 & -21.7 \\
\hline Bihar & 9.6 & -38.6 & -361.1 & 12.3 & -228.4 & -43.5 & NA & -32.7 & -51.1 & -10.0 & 45.4 & -19.9 & -44.8 & 15.8 & NA \\
\hline $\begin{array}{l}\text { Himachal Pra- } \\
\text { desh }\end{array}$ & 8.5 & 6.6 & 45.8 & -66.9 & -14.8 & 7.3 & NA & -29.6 & -68.9 & -4.5 & 128.4 & 6.9 & -44.2 & -30.7 & NA \\
\hline Orissa & -51.6 & -8.3 & 81.0 & -30.1 & -22.0 & -77.6 & NA & 43.6 & 5.3 & -0.7 & -15.0 & 9.8 & -25.4 & -55.4 & NA \\
\hline $\begin{array}{l}\text { Jammu and } \\
\text { Kashmir }\end{array}$ & 45.1 & -3.8 & -26.1 & -151.8 & -18.2 & -22.6 & -1.1 & -167.1 & -105.1 & -47.8 & -43.3 & -56.8 & -28.2 & -31.6 & NA \\
\hline Punjab & NA & -10.2 & -11.0 & -5.2 & -13.7 & -76.3 & -40.0 & -13.3 & -6.3 & -114.5 & -24.7 & 0.2 & 3.3 & -2.9 & -14.0 \\
\hline Uttarakhand & 2.7 & -98.6 & -67.1 & -96.0 & -39.6 & -22.0 & 46.0 & -107.9 & 3.5 & -18.9 & -48.6 & -214.2 & -274.9 & -64.9 & 67.9 \\
\hline Jharkhand & -113.2 & -25.2 & NA & NA & -31.2 & 5.4 & -94.0 & 1.6 & -7.8 & -33.4 & -10.6 & -21.9 & -28.3 & -80.2 & 3.0 \\
\hline Chhattisgarh & -165.5 & -189.4 & NA & -651.8 & -107.6 & -289 & -69.1 & 42.0 & -271.0 & -156.7 & -74.6 & -161.2 & -93.9 & - & 179.6 \\
\hline Mean & -26.4 & -20.4 & -23.0 & -69.1 & -44.1 & -32.7 & -53.3 & -16.8 & -30.9 & -30.8 & -9.6 & -28.1 & -31.0 & -28.8 & 13.4 \\
\hline
\end{tabular}

except the Transport Equipment (34).

Table 5 shows the mean TFP growth across 19 major Indian states and 15 different industries.

Few important observations can be made from Table 5. First, Haryana, Madhya Pradesh, Maharashtra, Bihar and Orrisa (highlighted cells) are the 5 states where TFP growth has seen a turnaround from negative to positive direction. Incidentally, all these states are large to medium in size. Second, Other Transport equipment (35) is the only industry that saw positive TFP growth across 6 medium sized states: Haryana, Madhya Pradesh, Maharashtra, Bihar, Orrisa and Chhattisgarh. It is no surprise as majority of these states are rich in natural resources. Third, during this period only Rubber (24) saw maximum fluctuation in its TFP growth across the states. Interestingly $50 \%$ of the rubber is being used by Motor Vehicles Industry and that also observed the similar fluctuations at the same period. Fourth, the highest mean TFP has been recorded by Coke and Refined Petroleum products (23). Interestingly, this is one of the top 5 exporting 
Table 5. Mean TFP Growth across 19 Different States of India for 15 Different Industries for 2005-11.

\begin{tabular}{|c|c|c|c|c|c|c|c|c|c|c|c|c|c|c|c|}
\hline \multicolumn{16}{|c|}{ Second half-2005-2011 } \\
\hline $\begin{array}{c}\text { Industry } \\
\text { Code/States }\end{array}$ & 16 & 17 & 18 & 19 & 20 & 21 & 23 & 24 & 25 & 26 & 27 & 28 & 29 & 34 & 35 \\
\hline $\begin{array}{l}\text { Andhra } \\
\text { Pradesh }\end{array}$ & -4.4 & -10.0 & -18.0 & -34.7 & 0.5 & 34.4 & -1.2 & -6.4 & -20.7 & -24.4 & -8.4 & -36.9 & -22.9 & -12.5 & -19.6 \\
\hline Gujarat & -3.3 & -7.4 & -2.8 & -26.0 & -57.0 & -10.5 & -7.0 & -4.1 & -14.2 & -15.0 & 13.5 & -20.8 & -13.3 & -0.2 & -29.1 \\
\hline Haryana & 21.4 & -9.4 & -10.0 & -32.0 & -29.7 & 9.4 & 64.4 & 6.9 & 1.7 & -8.2 & -20.7 & -18.0 & -17.8 & 13.7 & 2.1 \\
\hline Karnataka & -12.7 & -5.5 & -13.3 & -44.3 & 22.8 & -5.4 & -5.2 & 14.5 & 36.7 & -18.7 & -49.8 & -47.7 & -16.1 & -10.8 & -41.1 \\
\hline Kerala & 0.0 & -254.0 & -15.5 & -75.8 & -27.3 & -23.6 & 80.7 & -9.8 & -18.3 & -8.0 & -13.1 & -80.7 & -3.5 & -44.0 & -22.3 \\
\hline $\begin{array}{l}\text { Madhya } \\
\text { Pradesh }\end{array}$ & -3.6 & 2.6 & -54.3 & 11.4 & -14.2 & -22.9 & 143.3 & -13.0 & -30.9 & -10.1 & -80.3 & -19.2 & 14.5 & 17.7 & 19.2 \\
\hline Maharashtra & -35.9 & 7.8 & 25.3 & -17.7 & -30.8 & 3.9 & -13.1 & 0.9 & 8.2 & 11.2 & -16.2 & -26.4 & 12.6 & -7.9 & 5.2 \\
\hline Uttar Pradesh & -16.2 & 0.0 & -11.7 & -11.1 & 311.4 & -5.3 & -362.9 & -3.7 & -9.3 & -6.5 & -10.1 & -11.5 & -11.3 & -33.3 & -17.0 \\
\hline Rajasthan & -13.8 & -1.5 & -24.0 & -22.4 & -5.1 & -69.3 & -41.3 & -54.3 & -6.0 & -16.5 & -17.9 & -69.1 & -51.0 & -81.4 & -17.6 \\
\hline West Bengal & -11.7 & 0.8 & -47.7 & -25.3 & -19.5 & -11.7 & -7.6 & 1.9 & -19.4 & -4.3 & -20.6 & -30.5 & -9.8 & -2.1 & -1.6 \\
\hline Tamil Nadu & -34.2 & 1.2 & -18.1 & -18.0 & 14.1 & -8.7 & -10.1 & -10.3 & -10.5 & -8.4 & -24.7 & -32.8 & -28.1 & -15.4 & -23.6 \\
\hline Bihar & -29.9 & 6.0 & & 4.3 & 19.6 & 19.8 & -70.6 & -44.3 & 151.6 & 27.8 & 30.7 & 31.8 & $\begin{array}{c}-205 . \\
1\end{array}$ & & 12.31 \\
\hline $\begin{array}{c}\text { Himachal } \\
\text { Pradesh }\end{array}$ & -37.0 & -0.3 & 14.4 & -40.4 & -34.1 & -62.3 & NA & -37.0 & -44.5 & -4.0 & -66.9 & 9.7 & -48.2 & -79.0 & NA \\
\hline Orissa & 6.1 & 1.5 & & & -12.4 & 23.1 & -88.2 & 206.3 & -61.9 & -34.0 & 9.0 & -27.5 & -58.1 & 691.2 & \\
\hline $\begin{array}{c}\text { Jammu and } \\
\text { Kashmir }\end{array}$ & NA & -5.6 & 16.0 & 68.0 & -15.9 & 89.2 & 77.0 & -42.2 & -58.4 & -7.3 & -58.5 & -10.2 & -46.1 & & -9.3 \\
\hline Punjab & NA & -14.0 & -86.6 & -17.6 & -7.3 & -5.8 & -132.0 & -211.1 & -14.0 & -18.6 & -20.3 & -13.5 & -17.1 & -10.5 & -9.6 \\
\hline Uttarakhand & NA & -56.0 & -13.5 & -110.2 & -78.3 & -15.3 & 0.0 & -38.8 & -48.8 & -25.2 & -56.7 & -116.4 & $\begin{array}{c}-110 . \\
2\end{array}$ & -284.2 & -103.5 \\
\hline Jharkhand & -54.5 & -115.8 & 0.0 & NA & 481.4 & -246.6 & -171.4 & -159.3 & -252.2 & -240.7 & 4.8 & -537.4 & 300.4 & -297.6 & -548.7 \\
\hline Chhattisgarh & -10.8 & -270.1 & NA & -29.6 & -368.5 & 46.7 & 1086.0 & -283.3 & 792.9 & -137.0 & -11.0 & -511.4 & -72.6 & - & 1025.5 \\
\hline Mean & -18.5 & -40.0 & -19.4 & -26.6 & 5.8 & -19.7 & 22.9 & -37.0 & 3.1 & -32.9 & -26.1 & -82.5 & -24.1 & -13.7 & 11.0 \\
\hline
\end{tabular}

products (Pradhan, Das, 2015). Fifth, Manufacturer of Tobacco products (16) and Fabricated Metal Products (28) have seen the negative mean TFP growth in this period. While Fabricated Metal Products is a cyclical industry, the reason Tobacco product observed the negative TFP growth is due to restrictions imposed by government i.e. Smoking in public places was prohibited nationwide from 2 October 2008 under the Prohibition of Smoking in Public Places Rules, 2008 and COTPA. Sixth and finally, Uttarakhand, Punjab and Rajasthan have recorded mean negative TFP growth across all 15 industries.

\section{Conclusions and Policy Recommendations}

Six key conclusions are drawn from this study. First, the results indicate that the TFP growth for the period 1999-04 and 2005-11 differed greatly. TFP growth 
was certainly better for 2005-11 over to 1999-04. The growth was led by 5 medium to large states namely: Haryana, Madhya Pradesh, Maharashtra, Bihar and Orrisa. While Orissa recorded the highest positive TFP growth for the period of 2005-11, Jharkhand recorded the highest negative TFP growth at the same time.

Second, the top 5 states that recorded the positive TFP growth underwent a significant infrastructure boost. While Haryana and Maharashtra upped the infrastructure investment in early 2000, Bihar, Orissa and MP started promoting it in the middle of that decade. This infers to the fact that infrastructure promotes TFP growth. Therefore, author suggests investing into infrastructure (economics factor) to boost economic growth for the slightly backward states such as Jharkhand, Uttarakhand and Himachal Pradesh.

Third, it is interesting to note that Orissa and Bihar that are termed as backward states are among the five states that led the growth for 2005-11. In both states, economic reforms (economics factor) and strong political leadership (political factor) played a significant role. While in Orissa, infrastructure sector such as steel and power led the growth, in Bihar, it was ease for doing business. This concludes to the fact that economic reforms are key drivers to boost the TFP growth. Author suggests to kick start the economic reforms for the slightly backward states such as Jharkhand, Uttarakhand and Himachal Pradesh to boost the economic growth.

Fourth, an interesting observation was reported in case of Punjab which despite of being a relatively prosperous state reported a negative TFP growth rate during both the time periods taken by this paper. Interestingly, it is due to their high fiscal deficit. This concludes to the fact that financial prudence and expenditure need to be kept in check. Farm loan waivers, subsidized good, freebies, bailouts can only lead to high fiscal deficit and may hamper TFP growth.

Fifth, government should promote those industries locally that could leverage the raw material or natural resources available within states (social and local factor). For an example: Other Transport Equipment (35) is the only industry that saw positive TFP growth across 6 medium sized states: Haryana, Madhya Pradesh, Maharashtra, Bihar, Orrisa and Chhattisgarh for the period of 1999-04. Majority of these states are rich in natural resources and this was well utilized by Transport Equipment industry promoted by state governments.

Sixth and finally, government should promote export (economic factor) to boost economic growth. An example in this regard is Coke and Refined Petroleum Products (23) which recorded a highest mean TFP growth for the period of 1999-04. This is one of the top products that are exported from India.

Three main implications follow from this analysis. First, when considering recommendations for industry and states, the geographical factors need to be considered such as local, economic, social and political factors. Second, the paper considers 15 manufacturing industries and the results cannot be generalized for other industries. Third and lastly, the analysis needs to be compared with the other studies and must be validated by employing several other techniques with the same datasets. 
The findings of this paper provide scope for future studies such as: (I) Investigating further as why some industries are consistently observing negative productivity growth such as woodland products across states (II) which industries are driving TFP growth and why? (III) Differences in the TFP growth of formal vs. informal sectors (IV) Growth of Cyclical industry such as Rubber across states (V) Comparing the TFP growth between traditional vs. modern industries

On recalling the famous German writer, Thomas Mann, who said: "simplification is the first step towards mastery of a subject"; this paper tried to simplify the complex topic of comparative productivity analysis for India with the aim that future researchers can take this journey to even further.

\section{References}

[1] Kathuria, V., Raj, R.S.N. and Sen, K. (2013) Productivity Measurement in Indian Manufacturing: A Comparison of Alternative Methods. Journal of Quantitative Economics, 11, 148-179.

[2] Singh, A.P. (2016) Do Technology Spillovers Accelerate Performance of Firms? Unravelling a Puzzle from Indian Manufacturing Industry. Economics and Applied Informatics, 26, 108-120.

[3] Olley, S. and Pakes, A. (1996) The Dynamics of Productivity in the Telecommunications Equipment Industry. Econometrica, 65, 292-332.

[4] Levinsohn, J. and Petrin, A. (2003) Estimating Production Functions Using Inputs to Control for Unobservable. Review of Economic Studies, 70, 317-341. https://doi.org/10.1111/1467-937X.00246

[5] Ackerberg, D.A., Caves, K. and Frazer, G. (2006) Structural Identification of Production Functions. Mimeo, UCLA Department of Economics.

[6] Wooldridge, J.M. (1996) Estimating Systems of Equations with Different Instruments for Different Equations. Journal of Econometrics, 74, 387-405. https://doi.org/10.1016/0304-4076(95)01762-3

[7] Goldar, B. (1986) Productivity Growth in Indian Industry. Allied Publishers, New Delhi.

[8] Goldar, B. (2006) Productivity Growth in Indian Manufacturing in the 1980s and 1990s. In: Tendulkar, S.D., Mitra, A., Narayanan, K. and Das, D.K., Eds., India: Industrialization in a Reforming Economy, Academic Publishers, New Delhi.

[9] Goldar, B. and Kumari, A. (2003) Import Liberalization and Productivity Growth in Indian Manufacturing Industries in the 1990s. The Developing Economies, 41, 436460. https://doi.org/10.1111/j.1746-1049.2003.tb01010.x

[10] Kulshreshtha, M. and Parikh, J. (2002) Study of Efficiency and Productivity Growth in Opencast and Underground Coal Mining in India: A DEA Analysis. Energy Economics, 24, 439-453. https://doi.org/10.1016/S0140-9883(02)00025-7

[11] Deshpande, A. and Weisskopf, T. (2014) Does Affirmative Action Reduce Productivity? A Case Study of the Indian Railways. World Development, 64, 169-180.

[12] Mitra, A., Sharma, C. and éganzonès-Varoudakis, M. (2014) Trade Liberalization, Technology Transfer, and Firms' Productive Performance: The Case of Indian Manufacturing. Journal of Asian Economics, 33, 1-15.

[13] Sharma, C. and Mishra, R.K. (2015) International Trade and Performance of Firms: 
Unraveling Export, Import and Productivity Puzzle. The Quarterly Review of Economics and Finance, 57, 1-14.

[14] Kathuria, V., Raj, R.S.N. and Sen, K. (2010) Organized versus Unorganized Manufacturing Performance in the Post-Reform Period. Economic and Political, 45, 5564.

[15] Mitra, A., Sharma, C. and éganzonès-Varoudakis, M. (2016) Infrastructure, Information \& Communication Technology and Firms' Productive Performance of the Indian Manufacturing. Journal of Policy Modeling, 38, 353-371.

[16] Krishna, P. and Mitra, D. (1998) Trade Liberalization, Market Discipline and Productivity Growth: New Evidence from India. Journal of Development Economics, 56, 447-462.

[17] Unel, B. (2003) Productivity Trends in India's Manufacturing Sectors in the Last Two Decades. IMF Working Paper No. WP/03/22.

[18] Singh, A.P. (2016) R\&D Spillovers \& Productivity Growth: Evidence from Indian Manufacturing. Indian Journal of Industrial Relations, 51, 563-579.

[19] Krishna, K.L. and Kapila, U. (2009) Readings in Indian Agriculture and Industry. Academic Foundation, 402-403.

[20] India Ministry of Tourism (2014) Final Report of 20 Years Perspective Plan for Sustainable Development of Tourism in Jammu \& Kashmir. 